\title{
DIET KONSUMSI MAKANAN DAN PARENTAL FEEDING PADA KASUS STATUS GIZI LEBIH ANAK USIA DINI (Studi Kasus di RA Multazam Cimahi)
}

\author{
Arifah A. Riyanto ${ }^{1}$, Siti Khodijah ${ }^{2}$ \\ ${ }^{1,2}$ PG-PAUD STKIP Siliwangi Bandung \\ 1arifahastim@yahoo.com
}

\begin{abstract}
Abstrak
Status gizi lebih dan status gizi kurang/buruk, disatu sisi mengalami perbaikan dari status kurang/buruk menjadi status gizi normal dan disisi lain status gizi lebih semakin meningkat secara signifikan, sehingga dapat menyebabkan kegemukan atau obesitas. Penelitian ini bertujuan untuk mengetahui diet konsumsi makanan dan parental feeding pada kasus status gizi lebih anak usia dini. Tahapan-tahapan penelitian: a) studi pendahuluan untuk melihat status gizi anak usia dini; b) memilih anak status gizi lebih sebagai subjek penelitian; c) melakukan penyebaran angket dan wawancara diet konsumsi dan parental feeding kepada orang tua anak. Desain penelitian adalah deskriptif kualitatif, pendekatan penelitian dengan menggunakan kualitatif dan kuantitatif dengan metode yang digunakan adalah studi kasus. Hasil yang diperoleh yaitu status gizi lebih/obesitas pada anak disebabkan karena berbagai faktor antara lain karena diet konsumsi anak meliputi jenis dan porsi makanan yang anak konsumsi dalam satu hari, intensitas makan dalam satu hari. Selain itu juga karena pola asuh makan orang tua yang membebaskan anak makan sesuai keinginan anak, aktivitas anak yang kurang, makan sambil nonton dan beberapa disebabkan karena faktor keturunan. Dengan hasil tersebut diharapkan angka kejadian obesitas pada anak dapat ditekan.
\end{abstract}

Kata Kunci: Diet Konsumsi, Parental Feeding, Status Gizi, Obesitas pada Anak Usia Dini.

\begin{abstract}
More nutritional status and poor nutritional status, on the one hand improved from the status of less / bad to normal nutritional status and on the other hand more nutritional status increased significantly, which can lead to obesity or obesity. This study aims to determine the diet of food consumption and parental feeding in case of more nutritional status of early childhood. Research stages: a) preliminary study to look at early childhood nutritional status; b) choosing more child nutritional status as a research subject; c) conduct questionnaires and interviews of consumption and parental feeding to parents of children. The research design is descriptive qualitative, research approach using qualitative and quantitative with the method used is case study. The results obtained are more nutritional status / obesity in children caused by various factors, among others, because the consumption of children's diet includes the type and portion of food that children consume in one day, the intensity of eating in one day. In addition, because the parenting pattern of eating parents who free children to eat according to the wishes of children, less child activity, eating while watching and some due to hereditary factors. With these results are expected number of obesity in children can be suppressed.
\end{abstract}

Keywords: Consumption Diet, Parental Feeding, Nutritional Status, Obesity in Early Childhood. 


\section{Pendahuluan}

Permasalahan ganda gizi (double burden nutrition) pada kurun waktu belakangan ini mulai terlihat. Permasalahan ganda ini adalah status gizi lebih dan status gizi kurang/buruk. Di satu sisi status gizi anak Indonesia mengalami perbaikan yaitu dari status kurang/buruk menjadi status gizi normal, akan tetapi di sisi lain status gizi lebih semakin terlihat cukup signifikan peningkatannya. Jika pada tahun 2013, hasil Riset Kesehatan Dasar mengindikasikan anak di Indonesia mengalami gizi kurang sebesar 13.9 persen dan gizi buruk 5.7 persen. Pada tahun 2015, anak yang mengalami gizi buruk $\begin{array}{llll}\text { hanya } & \text { sekitar } & 3.8 & \text { persen }\end{array}$ (www.depkes.go.id). Dengan demikian terjadi penurunan signifikan pada 2 tahun berjalan yaitu dari 5.7 persen anak dengan gizi buruk menjadi 3.8 persen saja. Akan tetapi, peningkatan prevalensi status gizi lebih pada anak usia dini mencapai angka 5.3 percen. Hal ini menunjukkan perlu ada-nya perhatian khusus terhadap masalah status gizi lebih pada anak usia dini.

Status gizi lebih pada anak usia dini apabila dibiarkan akan mengakibatkan anak menderita obesitas pada usia dewasa kelak. Menurut Riskesdas tahun 2010, rata-rata prevalensi obesitas pada anak di Indonesia sekitar 14 persen (www.depkes.go.id). Obesitas disebab-kan karena multifaktoral antara lain asupan nutrisi, pola makan, jenis makanan yang dikonsumsi, gaya hidup, minim aktivitas fisik, genetik, hormonal, sosial ekonomi keluarga, lingkungan dan pola asuh (Putra, 2013). Namun faktor yang paling utama yang mengakibatkan obesitas pada anak usia dini adalah asupan makanan, aktifitas fisik dan pola asuh orang tua.

Obesitas berdampak buruk terhadap kesehatan anak antara lain akan mengakibatkan resiko obesitas pada usia dewasa kelak. Juga implikasi klinis terhadap kesehatan yaitu timbulnya penyakit-penyakit degenaratif di usia produktif seperti penyakit kardiovaskuler, hipertensi, diabetes melitus dan kanker (Barasi, 2007: 104). Hal ini tentu akan menurunkan kualitas hidup dan berpengaruh buruk terhadap pertumbuhan fisik anak yang akhirnya dapat mempengaruhi produktivitas.

Pola asuh makan (parental feeding) terhadap diet konsumsi makanan pada anak usia dini dengan status gizi lebih merupakan salah satu cara yang dapat dilakukan untuk mencegah dan mengatasi kejadian obesitas pada anak. Nilai-nilai dalam keluarga dapat membentengi anak dalam menerima atau menolak nilai-nilai di lingkungan-nya (Natsiopoulou et.al., 2007). Dan ibu memiliki peran besar dalam membentuk kebiasaan makan anak. Sebagaimana dikemukakan oleh Birch \& Fisher (1997: 542):

Infant dietary experiences is shaped by infant-feeding decisions and dietary pattern of the mother, and it provides the basis for food acceptance and pattern of intake in infancy.

Berdasarkan paparan tersebut maka penelitian dengan judul "Diet Konsumsi Makanan dan Parental Feeding pada Kasus Status Gizi Lebih Anak Usia Dini (Studi Kasus di RA Multazam, Cimahi)" merupakan salah satu langkah dalam menanggulangi angka kejadian obesitas pada anak usia dini dan diharapkan dapat menekan angka kejadian obesitas.

Yang menjadi permasalahan dalam penelitian ini, perlu ditelusuri penyebab obesitas pada anak terutama "Bagaimana diet konsumsi anak dan parental feeding yang mengakibatkan obesitas pada anak ?". Dengan data-data tersebut maka dapat dijadikan pijakan program yang dapat dibuat guru dan orang tua untuk mengatasi dan menghambat angka obesitas pada anak usia dini sehingga produktivitas generasi penerus bangsa dapat dijaga.

Adapun tujuan penelitian ini, yaitu :

1. Mengetahui gambaran secara umum kecenderungan status gizi anak usia dini di RA Multazam Kota Cimahi. 
2. Mengetahui diet konsumsi anak yang memiliki prevalensi gizi lebih/ obesitas di RA Multazam.

3. Mengetahui parental feeding pada anak dengan status gizi lebih/ obesitas di RA Multazam Kota Cimahi.

4. Mengetahui langkah apa saja yang dapat dilakukan untuk mengatasi kecenderungan status gizi lebih/ obesitas pada anak usia dini tersebut.

Melalui penelitian ini, dengan mengetahui diet konsumsi dan parental feeding yang mengakibatkan angka kejadian obesitas pada anak usia dini, dapat menjadi gambaran dan patokan bagaimana menekan angka kejadian obesitas baik pada usia dini maupun di usia anak dewasa kelak. Dengan demikian diharapkan dapat menjadi sumbangan bagi ilmu pengetahuan khususnya di bidang kesehatan dan gizi bagi anak usia dini dan sebagai langkah awal guna mendukung produktivitas generasi penerus dengan mempersiap-kan generasi yang sehat, cerdas dan produktif.

\section{KAJIAN PUSTAKA}

\section{A. Diet Konsumsi}

Beberapa hal yang harus diperhati-kan dalam membentuk diet konsumsi harian yang sehat bagi anak antara lain adalah: 1) membiasakan sarapan sehat yang mengandung gizi lengkap, 2) minum susu pada pagi hari, 3) kombinasi aneka ragam makanan, 4) mengatur dan membiasakan jajan sehat, 5) membatasi konsumsi junk food dan 6) minum air putih 7-8 gelas per hari (Khomsan, 2006).

Diet konsumsi anak yang dianjurkan pada balita usia 1-5 tahun yang dapat memenuhi angka kecukupan gizi anak berdasarkan Angka Kecukupan Gizi 2004 disajikan dalam tabel dibawah ini:

Tabel 2.1. Jumlah Bahan Makanan Rata-rata Sehari Balita Usia 1-5 Tahun.

\begin{tabular}{|l|c|c|}
\hline \multirow{2}{*}{$\begin{array}{c}\text { Anjuran } \\
\text { makanan }\end{array}$} & \multicolumn{2}{|c|}{ Usia } \\
\cline { 2 - 3 } & $\begin{array}{c}\mathbf{1 - 3} \\
\text { tahun }\end{array}$ & $\begin{array}{c}\mathbf{4 - 5} \\
\text { tahun }\end{array}$ \\
\hline Nasi & $3 \mathrm{p}$ & $4 \mathrm{p}$ \\
\hline Ikan/daging/telur & $1 \mathrm{p}$ & $2 \mathrm{p}$ \\
\hline
\end{tabular}

\begin{tabular}{|l|c|c|}
\hline \multicolumn{1}{|c|}{$\begin{array}{c}\text { Anjuran } \\
\text { makanan }\end{array}$} & \multicolumn{2}{c|}{ Usia } \\
\cline { 2 - 3 } & $\begin{array}{c}\mathbf{1 - 3} \\
\text { tahun }\end{array}$ & $\begin{array}{c}\mathbf{4 - 5} \\
\text { tahun }\end{array}$ \\
\hline Tempe/tahu & $1 \mathrm{p}$ & $1 \mathrm{p}$ \\
\hline Sayuran & $1 \mathrm{p}$ & $2 \mathrm{p}$ \\
\hline Buah & $2 \mathrm{p}$ & $3 \mathrm{p}$ \\
\hline Susu & $1 \mathrm{p}$ & $1 \mathrm{p}$ \\
\hline Minyak & $2 \mathrm{p}$ & $4 \mathrm{p}$ \\
\hline Gula Pasir & $2 \mathrm{p}$ & $2 \mathrm{p}$ \\
\hline
\end{tabular}

Sumber : Istiany \& Rusilanti, (2013, hlm 128)

$$
\mathrm{p}=\text { penukar }
$$

\section{B. Pola Asuh Makan atau Parental Feeding}

Pada usia dini, pola asuh makan orang tua terutama ibu sangat menentukan kondisi status gizi anak. Contento et al., (dalam Brown dan Jane, 2004: 262) menemukan hubungan antara motivasi ibu tentang kesehatan dengan kualitas asupan gizi anak.

Penelitian yang dilakukan Christiansen, et.al. (2013) menghasilkan kerangka lingkungan ekologi yang mempengaruhi kebiasaan makan anak usia 10-16 tahun yaitu faktor keluarga, teman, sekolah, dan lingkungan sekitar.

Sunaryo dalam Istiany dan Rusilanti (2013) menyatakan bahwa perkembangan anak balita sangat dipengaruhi oleh ibu, karena ibu-lah yang paling dominan dalam pengambilan keputusan pola pengasuhan kepada anak.

Birch et al., (2007), "Parents influence children's eating behavior in a variety of ways: parents actively make food choice for the family, serve as models for dietary choice and patterns, ad use feeding practices to reinforce the development of eating patterns and behaviors that they deem appropriate".

Shim, et al., (2011: 1363): "Food preferences is developed not only from genetically determined predispositions, but can also be modified by experiences, such as repeated exposure, feeding context, and social and physiological consequences".

Menurut penelitian Wardle (2002), pola asuh makan yang mendorong resiko 
obesitas dikelompokkan menjadi 4 kelompok yaitu emotional feeding (memberikan makanan agar anak tenang), instrumental feeding (memberikan penghargaan lewat makanan), prompting or encouragement to eat (mendorong makan dan memuji) dan control over eating (keluarga memutuskan apa yang anak makan).

\section{Status Gizi}

Dampak fisiologi dan fungsional dari gizi kurang antara lain : (1) gangguan pertumbuhan; (2) berkurang-nya fungsi imun dan meningkatnya resiko infeksi; (3) gangguan perkembangan kognitif; (4) pada kehamilan berakibat buruk bagi ibu dan bayi; (5) kemampuan bekerja terbatas; (6) peningkatan resiko penyakit kronik di kemudian hari dan (7) cedera dan trauma sukar sembuh (Barasi, 2007 : 14). Sedangkan gizi lebih dan diet yang tidak seimbang dapat meningkatkan morbiditas dan mortalitas karena penyakit-tidak menular terkait-gizi (Nutrition-Related Non-Comunicable Deseases, NR-NCD) seperti misalnya diabetes tipe 2 , penyakit kardiovaskuler, sindrom metabolik dan beberapa jenis kanker (Barasi, 2007, hlm 16).

Anak Usia Dini termasuk ke dalam kelompok rawan gizi. Kelompok rawan gizi adalah kelompok yang berada pada suatu siklus pertumbuhan atau perkembangan sehingga memerlukan zatzat gizi yang lebih besar dari kelompok umur yang lain. Kelompok rawan gizi tersebut antara lain: (a) kelompok bayi yaitu rentang usia 0-1 tahun; (b) kelompok usia balita yaitu 1-5 tahun; (c) kelompok anak sekolah yaitu usia 6-12 tahun; (d) kelompok remaja yaitu usia 13-20 tahun; (e) kelompok ibu hamil dan menyusui dan (f) kelompok usia lanjut.

\section{Obesitas pada Anak Usia Dini}

Menurut Barasi (2007 : 111), diet konsumsi untuk mencegah dan menanggulangi obesitas antara lain sebagai berikut: perlunya perencanaan pola makan yang sehat dan rasional dengan mengurangi konsumsi energi, diet yang mempertahankan rasa kenyang, diet yang menyesuaikan dengan kandungan makronutrien, diet yang menetapkan komposisi hidangan atau waktu makan, diet yang mengisi sistem pencernaan terlebih dahulu sebelum makan, diet yang menghindari makaanan yang dianggap memicu reaksi alergi, diet yang memerlukan suplemen, mengonsumsi hanya satu jenis makanan, puasa/tidak makan.

\section{METODOLOGI PENELITIAN}

Desain penelitian yang digunakan adalah deskriptif kualitatif, pendekatan penelitian dengan menggunakan kualitatif dan kuantitatif dengan metode yang digunakan adalah studi kasus. Pendekatan kualitatif digunakan karena didasarkan pada kenyataan bahwa masalah pada penelitian ini bersifat kekinian dan masih bersifat sementara sehingga sangat memungkinkan untuk berkembang menjadi lebih luas dan lebih dalam sesudah memasuki lapangan. Pendekatan kuantitatif hanya digunakan untuk menilai status gizi anak yang tentu saja akan melibatkan angka-angka seperti Berat Badan (BB) anak dan Tinggi Badan (TB), yang kemudian dengan menggunakan tabel status gizi IMT/U anak usia 5-18 Tahun yang dikeluarkan Kemenkes RI tahun 2010 dapat diketahui status gizi anak apakah normal, kurang, lebih atau bahkan obesitas.

Metode yang digunakan dalam penelitian ini adalah Studi Kasus karena pada penelitian ini bertujuan untuk mengeksplorasi proses, aktivitas dan peristiwa-peristiwa berkaitan dengan status gizi lebih pada anak dan faktor-faktor yang mempengaruhinya.

Subjek penelitian ini yaitu anak usia 56 tahun dan orang tua anak. Anak-anak yang dijadikan subjek penelitian diambil dari RA Multazam dan dipilih yang memenuhi kriteria yaitu anak yang memiliki berat badan lebih dari normal 
dan obesitas yang dilihat dan disesuaikan dengan tabel Status Gizi IMT/U yang dikeluarkan Kemenkes RI tahun 2010. Dari acuan itu diperoleh 9 anak yang memiliki berat badan diatas normal dan 5 anak dengan status gizi obesitas yang kemudian dijadikan subjek penelitian.

Teknik pengumpulan data yang digunakan, yaitu observasi, angket, wawancara dan dokumentasi.

Data kualititatif yang diperoleh melalui pedoman observasi, angket, wawancara dan dokumentasi kemudian dianalisis dengan menggunakan pengo-lahan data kualitatif dilakukan dengan cara memilah dan mengelompokan data berdasarkan klasifikasi data.

Aktivitas dalam analisis data kualitatif dilakukan secara interaktif dan berlangsung secara terus menerus sampai tuntas sehingga datanya jenuh. Aktivitas analisis data tersebut meliputi data reduction, data display, dan conclusion drawing/verification (Miles dan Huberman dalam Sugiyono, 2008). Sedangkan data kuantitatif dianaliasis dengan pedoman penentuan status gizi menggunakan metode antropometri berdasarkan Tabel IMT/U anak usia 5-18 tahun yang dikeluarkan Kemenkes RI tahun 2010.

\section{HASIL DAN PEMBAHASAN}

\section{A. Deskripsi Hasil Penelitian}

\section{Gambaran Secara Umum}

Kecenderungan Status Gizi Anak Usia Dini di RA Multazam Kota Cimahi.

Berdasarkan hasil yang diproleh ini, anak di RA Mutlazam yang memiliki status gizi lebih dan obesitas dijadikan subjek penelitian. Berikut ditampilkan data anak yang dijadikan subjek penelitian.

Tabel 4.1. Data Anak Gemuk dan

Obesitas di TK Multazam

Sebagai Subjek Penelitian.

\begin{tabular}{|c|c|c|c|c|c|}
\hline \multirow{2}{*}{ NO } & $\begin{array}{c}\text { Nama } \\
\text { Anak }\end{array}$ & \multicolumn{2}{|c|}{ Data Anak } & \multicolumn{2}{c|}{$\begin{array}{c}\text { Perhitungan } \\
\text { Antropometri }\end{array}$} \\
\cline { 3 - 6 } & & $\begin{array}{c}\text { BB } \\
\text { (kg) }\end{array}$ & $\begin{array}{c}\text { TB } \\
(\mathbf{c m})\end{array}$ & IMT/U & $\begin{array}{c}\text { Status } \\
\text { Gizi }\end{array}$ \\
\hline 1 & AA1 & 20 & $\begin{array}{c}105 . \\
5\end{array}$ & 17.97 & $\begin{array}{c}\text { Gemu } \\
\text { k }\end{array}$ \\
\hline
\end{tabular}

\begin{tabular}{|c|c|c|c|c|c|}
\hline \multirow{2}{*}{ NO } & \multirow[t]{2}{*}{$\begin{array}{l}\text { Nama } \\
\text { Anak }\end{array}$} & \multicolumn{2}{|c|}{ Data Anak } & \multicolumn{2}{|c|}{$\begin{array}{c}\text { Perhitungan } \\
\text { Antropometri }\end{array}$} \\
\hline & & $\begin{array}{c}\text { BB } \\
(\mathrm{kg})\end{array}$ & $\begin{array}{c}\mathrm{TB} \\
(\mathrm{cm})\end{array}$ & IMT/U & $\begin{array}{c}\text { Status } \\
\text { Gizi }\end{array}$ \\
\hline 2 & AA6 & 25 & 116 & 18.58 & $\begin{array}{c}\text { Gemu } \\
\mathrm{k}\end{array}$ \\
\hline 3 & AA7 & 24 & 113 & 18.8 & $\begin{array}{c}\text { Gemu } \\
\mathrm{k}\end{array}$ \\
\hline 4 & B12 & 24 & 113 & 17.83 & $\begin{array}{c}\text { Gemu } \\
\mathrm{k}\end{array}$ \\
\hline 5 & B18 & 40 & 122 & 27.6 & $\begin{array}{c}\text { Obesit } \\
\text { as }\end{array}$ \\
\hline 6 & $\begin{array}{l}\text { B21 } \\
4\end{array}$ & 23 & $\begin{array}{c}113, \\
5\end{array}$ & 18.01 & $\begin{array}{c}\text { Gemu } \\
\mathrm{k}\end{array}$ \\
\hline 7 & $\begin{array}{l}\text { B21 } \\
6\end{array}$ & 26 & 119 & 18.36 & $\begin{array}{c}\text { Gemu } \\
\mathrm{k}\end{array}$ \\
\hline 8 & \begin{tabular}{|l|} 
B21 \\
8 \\
\end{tabular} & 22 & $\begin{array}{c}117 \\
5\end{array}$ & 16.07 & $\begin{array}{c}\text { Gemu } \\
\mathrm{k}\end{array}$ \\
\hline 9 & $\begin{array}{l}\text { B31 } \\
0\end{array}$ & 27 & 114 & 20.78 & $\begin{array}{c}\text { Obesit } \\
\text { as }\end{array}$ \\
\hline $\begin{array}{l}1 \\
0\end{array}$ & $\begin{array}{l}\text { B31 } \\
4\end{array}$ & 27 & 110 & 22.31 & $\begin{array}{c}\text { Obesit } \\
\text { as }\end{array}$ \\
\hline $\begin{array}{l}1 \\
1\end{array}$ & \begin{tabular}{|l|} 
B411 \\
8 \\
\end{tabular} & 25 & 112 & 19.92 & $\begin{array}{c}\text { Gemu } \\
\mathrm{k}\end{array}$ \\
\hline $\begin{array}{l}1 \\
2\end{array}$ & \begin{tabular}{|l|} 
B42 \\
3 \\
\end{tabular} & 35 & $\begin{array}{c}130 \\
5\end{array}$ & 20.71 & $\begin{array}{c}\text { Obesit } \\
\text { as }\end{array}$ \\
\hline $\begin{array}{l}1 \\
3\end{array}$ & \begin{tabular}{|l} 
B42 \\
4
\end{tabular} & 24 & 114 & 18.46 & $\begin{array}{c}\text { Gemu } \\
\mathrm{k}\end{array}$ \\
\hline $\begin{array}{l}1 \\
4\end{array}$ & \begin{tabular}{|l|} 
B42 \\
5
\end{tabular} & 29 & 120 & 20.14 & $\begin{array}{c}\text { Obesit } \\
\text { as }\end{array}$ \\
\hline
\end{tabular}

Berdasarkan hasil tersebut, kemudian disebarkan angket yang akan diisi oleh orang tua untuk melihat diet konsumsi dan pola asuh makan orang tua pada anak yang gemuk dan obesitas tersebut untuk dapat menjawab pertanyaan penelitian selanjutnya.

\section{Gambaran Diet Konsumsi Makanan Anak yang Memiliki Prevalensi Gizi Lebih dan Obesitas di RA Multazam Kota Cimahi.}

Diet konsumsi anak dalam penelitian ini meliputi jumlah dan jenis makanan yang dikonsumsi anak. Jumlah makanan yang dikonsumsi anak meliputi jumlah sumber karbohidrat yang dikonsumsi, jumlah sumber protein yang dikonsumsi, jumlah makan dalam satu hari dan jumlah makanan camilan yang dikonsumsi. Jenis 
makanan yang dikonsumsi meliputi jenis sumber karbohidrat yang dikonsumsi, jenis sumber protein yang dikonsumsi, jenis sumber vitamin dan mineral yang dikonsumsi serta jenis camilan yang dikonsumsi.

Angket yang disebar pada 14 anak yang menjadi subjek penelitian, hanya 8 angket yang kembali, di antaranya ada tiga anak yang obesitas.

Berdasarkan hasil angket yang disebarkan pada orang tua anak dengan status gizi lebih/gemuk dan obesitas diperoleh hasil bahwa diet konsumsi anak secara garis besar memang berlebih, baik itu dalam porsi, seringnya makan, seringnya makan camilan dan sering jajan.

\section{Gambaran Parental feeding orang tua terhadap anak yang memiliki prevalensi status gizi lebih di RA Multazam Kota Cimahi.}

Parental Feeding atau pola asuh makan dalam penelitian ini meliputi sub aspek pengasuhan makan, menyediakan makan, dan membiasakan makan. Sub aspek pengasuhan makan meliputi memberitahu rasa lapar dan kenyang, mengatur jadwal makan, memberi hadiah makanan, kondisi makan (disuapi, sambil nonton, atau sesudah makan tidur), membebaskan makanan yang ingin dikonsumsi anak, Ibu atau anak yang memutuskan apa yang akan dikonsumsi anak, serta aktivitas main anak (motorik halus atau motorik kasar). Sub aspek menyediakan makan meliputi makanan apa yang disediakan untuk makan, makanan untuk camilan, menyediakan makanan atau membebaskan anak jajan untuk memenuhi kebutuhan makanan camilan anak. Serta sub aspek membiasakan makan meliputi membiasakan makan 3 kali dan camilan 2 kali dalam satu hari, membiasakan/membatasi jajan.

Berdasarkan hasil angket dan wawancara bahwa pola asuh makan pada anak sangat mempengaruhi diet konsumsi makan anak dalam setiap harinya. Sub aspek pengasuhan makan meliputi: memberitahu rasa lapar dan kenyang, mengatur jadwal makan anak, memberi hadiah makanan, kondisi makan (disuapi, sambil nonton, sesudah makan langsung tidur), membebaskan makanan yang dikonsumsi anak, Ibu/ anak yang memutuskan apa yang akan dikonsumsi anak dan aktivitas main anak (motorik kasar/motorik halus).

Dari hasil angket dan wawancara tersebut diperoleh hasil bahwa kebanyakan orang tua sudah mengenalkan rasa lapar dan kenyang pada anak. Mengatur jadwal anak dilakukan oleh sebagian orang tua akan tetapi belum dilakukan oleh sebagian lainnya. Memberi hadiah makanan menjadi hal yang lumrah dilakukan oleh para orang tua. Kondisi makan disuapi dan sambil nonton juga menjadi hal yang kebanyakan orang tua lakukan. Banyak orang tua yang masih membebaskan apa yang akan anak konsumsi. Serta aktivitas yang anak lakukan melalui permainan, kebanyakan lebih dominan menggunakan aktivitas dengan motorik halus, artinya banyak anak yang tidak banyak bergerak.

Sub aspek menyediakan makanan meliputi makanan apa yang disediakan, makanan untuk camilan, menyediakan makanan untuk camilan atau membebaskan anak jajan sebagai camilan. Berdasarkan hasil angket dan wawancara diperoleh hasil kebanyakan orang tua sudah dapat menyediakan makan untuk anak, akan tetap me-nyediakan variasi makanan masih relatif jarang, artinya makanan yang disedia-kan untuk anak belum banyak meng-gunakan sumbersumber karbohidrat, protein, vitamin dan mineral yang beragam hanya terbatas pada sumber tertentu saja. Masih terdapat beberapa orang tua yang tidak menyediakan makanan camilan untuk anak.

Selanjutnya sub aspek membiasakan makan anak meliputi membiasakan makan 3 kali dan camilan 2 kali, dan membiasakan/membatasi jajan. Ber- 
dasarkan hasil yang diperoleh dari angket dan wawancara diperoleh hasil bahwa kebanyakan orang tua tidak membiasakan makan 3 kali dan camilan 2 kali untuk memenuhi kebutuhan gizi anak dalam satu hari. Selain itu kebanyakan orang tua membebaskan anak untuk jajan, bahkan ada beberapa orang tua yang membebaskan jajan karena orang tua tidak menyediakan makanan camilan untuk anak.

\section{Mengatasi Kecenderungan Status Gizi Lebih dan Obesitas pada Anak Usia Dini Berdasarkan Hasil yang Diperoleh.}

Berdasarkan beberapa hasil yang diperoleh baik dari sisi diet konsumsi anak maupun dari parental feeding orang tua pada anak dengan status gizi lebih dan obesitas dapat ditarik kesimpulan bahwa beberapa hal yang dapat memicu terjadinya status gizi lebih dan obesitas pada anak usia dini dilihat dari aspek diet konsumsi anak diantaranya porsi makan yang melebihi batas yang seharusnya anak konsumsi, jenis dan jumlah camilan yang di-konsumsi anak, dan intensitas jajan. Hal ini tentu saja sangat terkait dengan kemampuan ibu dalam menyediakan makan serta membiasakan makan sehat, bergizi dan sesuai dengan kebutuhan anak.

Dari aspek pola asuh makan, yang memicu terjadinya status gizi lebih dan obesitas antara lain dari sub aspek pengasuhan makan, yaitu memberikan hadiah berupa makanan, kurang membiasakan makan dengan tidak menonton TV dan tidak disuapi, membebaskan apa yang akan anak konsumsi, serta aktivitas fisik yang kurang mengeksplor motorik kasar. Sub aspek menyediakan makan, yaitu kurang memvariasikan sumber-sumber bahan makanan, serta kemampuan menyiapkan makanan camilan bagi anak. Selanjutnya sub aspek membiasakan makan yaitu tidak membiasakan makan 3 kali dan camilan 2 kali dalam sehari menjadi suatu kebiasaan, membebaskan porsi yang akan anak konsumsi, membebaskan makanan camilan anak baik dari segi jenis maupun jumlah serta membebaskan jajan.

\section{B. Pembahasan}

1. Kecenderungan Status Gizi Anak Usia Dini di RA Multazam Kota Cimahi.

Diet konsumsi anak dalam satu hari harus sesuai dengan kebutuhan anak, tidak lebih maupun tidak kurang. Konsumsi yang lebih dari kebutuhan anak akan mengakibatkan status gizi anak menjadi berlebih atau bahkan obesitas. Sebaliknya jika konsumsi harian anak kurang maka akan mengakibatkan anak memiliki status gizi kurang. Kedua kondisi ini tidak baik terutama bagi anak dalam masa pertumbuhan. Status gizi berlebih akan mengakibatkan anak memiliki resiko obesitas di usia dewasa kelak. Dengan demikian akan menurunkan kualitas hidupnya. Obesitas akan memicu timbulnya beberapa penyakit degeneratif seperti diabetes, kanker bahkan penyakit jantung. Status gizi rendah akan mengakibatkan anak memiliki daya tahan tubuh yang rentan terhadap penyakit.

Diet konsumsi untuk memenuhi kebutuhan baik untuk anak maupun orang dewasa dikenal dengan istilah Angka Kecukupan Gizi atau disingkat AKG. Angka kecukupan gizi merupakan jumlah zat gizi yang disepakati dan dinilai cukup untuk memenuhi kebutuhan orang untuk tumbuh sehat.

Angka Kecukupan Gizi untuk anak usia 6-9 tahun adalah: Nasi/pengganti 2-3 piring, lauk hewani 2-4 potong, lauk nabati 2-3 potong, sayuran 1-11/2 mangkuk dan buah-buahan 2-3 potong. Nilai ini setara dengan kebutuhan energi 1600 kalori.

Pada anak, kecukupan gizi harian ini dapat dipenuhi dengan konsumsi makan sebanyak 3 kali dan makan camilan 2 kali. Hal ini disebabkan karena anak pada masa ini merupakan masa pilih-pilih makanan, sehingga kekurangan zat gizi yang tidak terpenuhi dari makan dapat ditutupi dengan makanan camilan. Dengan 
demikian makanan camilan haruslah merupakan makanan yang mengandung zat gizi seperti karbohidrat, protein maupun mineral yang tidak dipenuhi dalam konsumsi makan 3 kali. Jika kebutuhan karbohidrat dan protein sudah dapat dipenuhi dalam makan 3 kali, maka camilan anak dapat berupa buah dan sayur untuk memenuhi kebutuhan vitamin dan mineral. Apabila kebutuhan energi sudah terpenuhi dari makan 3 kali, akan tetapi ketika makan camilan juga diberi sumber protein atau karbohirat, maka akan mengakibatkan kelebihan energi yang kemudian disimpan pada tubuh anak dalam bentuk lemak. Terlebih jika aktivitas anak hanya terbatas pada permainan yang banyak menggunakan motorik halus, maka kelebihan ini akan tetap disimpan dalam tubuh anak. Lain halnya jika aktivitas anak banyak menggunakan permainan motorik kasar, maka kelebihan ini akan dibakar dijadikan energi untuk anak bermain.

Pada kenyataannya, camilan yang dikonsumsi anak kebanyakan berupa makanan jajanan anak dalam kemasan atau makanan junk food yang tentu saja dapat mengakibatkan resiko pada anak. Hal ini perlu menjadi perhatian orang tua karena segala yang anak konsumsi akan memberikan efek terhadap tubuh, baik itu efek positif maupun efek negatif, serta berpengaruh terhadap status gizi anak.

Berdasarkan hasil yang diperoleh dari tempat penelitian, dapat ditarik kesimpulan bahwa status gizi anak yang beragam baik status gizi kurang, normal, lebih atau obesitas ditentukan oleh diet konsumsi harian anak, baik dari konsumsi makan maupun makanan camilan anak. Status gizi kurang masih banyak terjadi di tempat penelitian, begitu pun dengan status gizi lebih dan obesitas. Hal ini menunjukkan kasus double borden (permasalahan ganda) gizi yang menimpa kebanyakan negara berkembang. Hal ini harus menjadi perhatian bersama. Penyelesaian masalah melalui pendekatan pendidikan harus sudah mulai dilakukan. Amerika Serikat berhasil menekan angka kejadian obesitas selama 10 tahun terakhir dan mampu menekan biaya kesehatan yang diakibatkan obesitas hingga 12 triliun rupiah melalui pendidikan gizi salah satunya program makan di sekolah (School Meal Programe), sedangkan Peru berhasil menurunkan angka kejadian stunting-nya selama tiga tahun (2000-2004) dari 54\% menjadi $37 \%$ melalui media pendidikan gizi (Adriyana, 2013).

Dengan demikian, melalui pen-dekatan pendidikan terutama pendidikan gizi merupakan salah satu jalan yang efektif mengatasi permasalahan ganda gizi yaitu status gizi kurang dan status gizi lebih/ obesitas.

\section{Diet Konsumsi Makanan Anak yang Memiliki Prevalensi Gizi Lebih dan Obesitas di RA Multazam Kota Cimahi.}

Penyebab gizi lebih ataupun obesitas sangat beragam. Obesitas disebabkan karena multifaktoral antara lain asupan nutrisi, pola makan, jenis makanan yang dikonsumsi, gaya hidup, minim aktivitas fisik, genetik, hormonal, sosial ekonomi keluarga, lingkungan dan pola asuh (Putra, 2013). Penyebab gizi lebih yang menjadi perhatian dalam penelitian ini adalah aspek diet konsumsi dan pola asuh makan.

Diet konsumsi pada anak yang mengakibatkan gizi lebih dan obesitas pada penelitian ini antara lain akibat asupan makan yang lebih dari angka kecukupan gizi anak seperti porsi makan yang menggunakan porsi dewasa, atau intensitas makan lebih dari $3 \mathrm{kali} / \mathrm{hari}$, dan kebanyakan makan camilan lebih dari 2 kali/hari dengan jenis makanan camilan yang kurang sehat dan melebihi kebutuhan energi yang sementara itu kebutuhan tersebut sudah terpenuhi pada makan 3 kali sehari. Dengan demikian terjadi penumpukan tambahan energi yang dimetabolisme oleh tubuh diubah dalam bentuk timbunan lemak dan mengakibatkan berat badan anak meningkat. 
Makanan camilan yang baik untuk dikonsumsi anak adalah makanan sehat yang dapat memenuhi kebutuhan anak yang tidak ditutupi dari makan 3 kali sehari. Jika kebutuhan tersebut sudah dapat dipenuhi makan 3 kali sehari, maka akan lebih baik jika makanan camilan anak berupa buah dan sayur yang ketika konsumsi berlebih tidak akan mengakibatkan penimbunan lemak dan peningkatan berat badan.

Disamping itu penyebab lainnya adalah intensitas jajan yang sering dengan jenis jajanan yang kurang sehat. Makanan junk food, makanan dalam kemasan dan makanan jajanan anak lainnya tidak dapat memenuhi kebutuhan zat gizi anak, akan tetapi memiliki kalori tinggi yang dapat menjadi salah satu penyebab status gizi lebih dan obesitas pada anak. Makanan tersebut memiliki zat gizi rendah dan bahkan mengandung Bahan Tambahan Makanan yang dapat ditimbun dalam tubuh dan merupakan zat asing bagi tubuh yang suatu saat jika sudah tertumpuk akan menimbulkan berbagai penyakit antara lain kanker.

Beberapa hal yang harus diperhatikan dalam membentuk pola makan yang sehat bagi anak antara lain adalah: 1) membiasakan sarapan sehat yang mengandung gizi lengkap, 2) minum susu pada pagi hari, 3) kombinasi aneka ragam makanan, 4) mengatur dan membiasakan jajan sehat, 5) membatasi konsumsi junk food dan 6) minum air putih 7-8 gelas per hari (Khomsan, 2006, hlm 44).

\section{Parental Feeding Orang Tua terhadap Anak yang Memiliki Prevalensi Status Gizi Lebih di RA Multazam Kota Cimahi.}

Orang tua masih belum memahami secara benar pola asuh makan yang baik untuk anak. Banyak orang tua yang masih membebaskan apa yang akan anak konsumsi. Membebaskan berlainan dengan menanyakan keinginan anak untuk membangun nafsu makan anak. Jika memang anak sudah memiliki nafsu makan yang baik, maka keputusan untuk memilih makanan sebaiknya dikendalikan oleh orang tua untuk menjaga status gizi atau berat badan anak tetap stabil.

Masa usia batita dan balita merupakan masa pilih-pilih makanan atau dikenal dengan istilah picky eater. "Picky eaters are characterized as consistently being unwilling to try new foods or having strong opinions on food preferences, preparation methods, and choice of food group" (Carrut BR, et al., 2004 and Carrut BR, et al., 1998 dalam Shim, et al., 2011: 1363). Masa ini merupakan masa pengenalan makanan baru bagi anak, akan tetapi kebanyakan anak tidak memiliki keinginan untuk mencoba, memilih atau bahkan menyukai makanan baru. Hal ini merupakan tantangan bagi orang tua untuk dapat mengenalkan makanan baru kepada anak dengan cara yang menyenangkan sehingga anak memiliki kesan baik terhadap makanan. Dengan demikian kemungkinan anak untuk menyukai buah dan sayur dan makanan bergizi lainnya semakin besar.

Selain itu orang tua perlu berhati-hati dengan pilihan anak karena selain anak belum memiliki pengetahuan yang cukup tentang kebutuhan zat gizi bagi masa pertumbuhannya, juga karena anak akan memilih makanan yang sesuai dengan keinginannya saja tanpa memperhatikan kebutuhan zat gizi harian yang harus dipenuhi.

Para ahli berbeda pendapat tentang faktor yang menyebabkan perilaku picky eaters. "Early exposure to fruit and vegetables during infancy may promote higher consumption in later childhood" (Cooke L, et al., 2003 dan Skinner JD, et. al., 2002 dalam Shim, et al., 2011: 1363).

Pemilihan makanan pada anak sangat dipengaruhi kebiasaan orang tua dalam menyediakan makanan. Pendapat Shim, et al., (2011: 1363): "Food preferences is developed not only from genetically determined predispositions, but can also be modified by experiences, such as repeated exposure, feeding context, and 
social and physiological consequences". Oleh karena itu orang tua perlu hati-hati ketika membebaskan apa yang akan dikonsumsi anak. Anak masih harus dalam dampingan orang tua dalam memutuskan apa yang akan ia konsumsi.

Membatasi jajan merupakan salah satu hal yang harus menjadi perhatian para ibu. Hal ini selain disebabkan karena efek jajan di usia dini akan menjadikan perilaku yang tidak baik terkait konsumsi makanan, dan akan menjadi kebiasaan yang menetap serta tentu saja akan perengaruh terhadap kondisi kesehatan anak. Makanan jajanan yang banyak beredar sekarang ini tentu tidak terlepas dari zat-zat kimia yang ditambahkan dalam makanan tersebut. Zat kimia ini tentu sedikitnya akan berpengaruh, karena di dalam tubuh akan tetap dianggap zat asing. Dengan demikian kerja fungsi hati akan bertambah keras untuk dapat menetralisisr zat tersebut.

\section{Mengatasi Kecenderungan Status Gizi Lebih dan Obesitas pada Anak Usia Dini Berdasarkan Hasil yang Diperoleh.}

Menurut Barasi (2007: 111), diet konsumsi untuk mencegah dan menanggulangi obesitas antara lain sebagai berikut: perlunya perencanaan pola makan yang sehat dan rasional dengan mengurangi konsumsi energi, diet yang mempertahankan rasa kenyang, diet yang menyesuaikan dengan kandungan makronutrien, diet yang menetapkan komposisi hidangan atau waktu makan, diet yang mengisi sistem pencernaan terlebih dahulu sebelum makan, diet yang menghindari makanan yang dianggap memicu reaksi alergi, diet yang memerlukan suplemen, mengonsumsi hanya satu jenis makanan, puasa/tidak makan.

Berdasarkan beragam cara yang diusulkan Barasi tersebut, hal yang bisa dilakukan pada anak antara lain dengan mengurangi konsumsi energi, perencanaan pola makan sehat dan rasional bagi anak, diet yang menetapkan komposisi hidangan atau waktu makan. Tambahan lain dari hasil penelitian adalah dengan mengurangi makanan camilan anak, mengganti makanan camilan anak dengan buah atau sayur, menyediakan makanan camilan di rumah sehingga dapat mengurangi jajan anak. Dengan menyediakan makanan camilan di rumah maka diharapkan konsumsi camilan anak dapat dikontrol oleh orang tua.

\section{SIMPULAN DAN SARAN}

\section{A. SIMPULAN}

Status gizi menentukan status kesehatan seseorang. Status gizi gemuk dan obesitas di usia dini memiliki resiko obesitas di usia dewasa kelak. Hal ini akan mengakibatkan penurunan kualitas hidup anak dan menurunkan produktivitasnya. Berbagai penyakit yang ditimbulkan akibat obesitas antara lain berbagai penyakit degeneratif seperti diabetes, kanker bahkan penyakit jantung.

Melalui penelitian ini diharapkan dapat menjadi gambaran beberapa hal yang dapat menyebabkan status gizi anak menjadi gemuk dan obesitas. Faktor yang menjadi perhatian dalam penelitian ini terutama terkait diet konsumsi anak dan pola asuh orang tua (parental feeding).

Berdasarkan hasil angket yang disebarkan pada orang tua anak dengan status gizi lebih/gemuk dan obesitas diperoleh hasil bahwa diet konsumsi anak secara garis besar memang berlebih, baik itu dalam porsi, seringnya makan, seringnya makan camilan dan sering jajan.

Orang tua masih belum memahami secara benar pola asuh makan yang baik untuk anak. Banyak orang tua yang masih membebaskan apa yang akan anak konsumsi. Membebaskan berlainan dengan menanyakan keinginan anak untuk membangun nafsu makan anak. Jika memang anak sudah memiliki nafsu makan yang baik, maka keputusan untuk memilih makanan sebaiknya dikendalikan oleh orang tua untuk menjaga status gizi atau berat badan anak tetap stabil. 
Beberapa cara yang dilakukan untuk menanggulangi dan menekan angka kejadian obesitas pada anak usia dini antara lain dengan mengurangi kon-sumsi energi, perencanaan pola makan sehat dan rasional bagi anak, diet yang menetapkan komposisi hidangan atau waktu makan. Tambahan lain dari hasil penelitian adalah dengan mengurangi makanan camilan anak, mengganti makanan camilan anak dengan buah atau sayur, menyediakan makanan camilan di rumah sehingga dapat me-ngurangi jajan anak. Dengan menyedia-kan makanan camilan di rumah maka diharapkan konsumsi camilan anak dapat dikontrol oleh orang tua.

\section{B. SARAN}

Saran yang dapat diajukan dari penelitian "Diet Konsumsi Makanan dalam Parental Feeding pada Kasus Status Gizi Lebih Anak Usia Dini" ini antara lain sebagai berikut:

\section{Saran untuk Orang Tua}

Orang tua merupakan pengemban tanggung jawab terhadap pertum buhan dan perkembangan anak. Anak dalam masa pertumbuhan nya memiliki ketergantungan yang sangat terhadap orang tua terutama Ibu yang akan mendampingi dan memenuhi segala kebutuhannya terutama kebutuhan terhadap makanan. Pada masa pertumbuhan ini, diet konsumsi dan pola asuh makan anak harus mendapat perhatian agar apa yang anak konsumsi merupakan makanan yang sehat dan bergizi serta memenuhi Angka Kecukupan Gizi anak tidak kurang ataupun berlebih. Pola asuh makan seperti membiasakan makan 3 kali dan camilan 2 kali dalam sehari perlu orang tua terapkan, jenis dan jumlah makanan camilan serta membatasi jajan.

2. Saran untuk Guru dan Sekolah

Sekolah perlu memiliki program terkait makanan dan zat gizi yang seharusnya anak konsumsi dan parenting orang tua. Program yang bisa diterapkan adalah program pendidikan gizi yang dapat dilakukan oleh guru kepada anak untuk menanamkan motivasi dan perubahan sikap terkait makanan sehat dan bergizi. Sedangkan sekolah memfasilitasi parenting untuk orang tua dalam menyediakan dan membiasakan makan sehat dan bergizi sehingga dapat mengontrol status gizi anak tetap dalam kisaran normal.

3. Saran untuk Penelitian Lebih Lanjut

Penelitian tentang status gizi anak agar terwujud status gizi yang normal dapat menjadi fokus penelitian selanjutnya dengan berbagai kondisi sehingga berbagai cara dan faktor dapat diketahui agar terbentuk status gizi normal pada anak usia dini untuk menciptakan generasi penerus yang sehat, cerdas dan ceria menyongsong Indonesia emas. Lokasi penelitian pun dapat dimana saja sehingga makin me-rata gerakan percepatan sadar kesehatan dan gizi melalui pendekatan pendidikan guna menyongsong Indonesia sehat.

\section{SUMBER PUSTAKA}

Adriyana. (2013). Empat Pilar Gizi Seimbang sebagai Media Pendidikan Gizi di Indonesia. [Online]. Available at: http://sisi.blogspot.com/2013/05/em pat-pilar.html?m=1 .

Barasi, M. E. 2007. At a Glance. Ilmu Gizi. Terjemahan. Jakarta: Penerbit Erlangga.

Birch, L.L. dan J. O. Fisher. (1997). Development of Eating Behavior Among Children and Adolescents. Journal of Pediatrics. 101, 539-549.

Christiansen, K.M.H., Qureshi, F., Schaible, A., Park, S., dan Gittelsohn, J. (2013). Environmental Factor That Impact The Eating Behaviors of Low-income African American Adolescents in Baltimore City. Journal of Nutrition Education and Behavior 45, (6); 652-660. http://dx.doi.org/10.1016/j.jneb.2013 .05.009.

Dewi. L. 2014. Pola Makan Sehat dan Gaya Hidup yang Benar. [Online]. 
Availabe

at: http://www.rumahsakitmitrakemayor an.com.

Irianto, D. J. (2007). Panduan Gizi Lengkap Keluarga dan Olahragawan. Yogyakart: Penerbit Andi

Istiany, A.dan Rusilanti. 2013. Gizi Terapan. Bandung: Penerbit PT Remaja Rosdakarya.

Kementerian Kesehatan RI. 2011. Standar Antropometri Penilaian Status Gizi Anak. Direktorat Jenderal Bina Gizi dan Kesehatan Ibu dan Anak.

Khomsan, A. 2006. Solusi Makanan Sehat. Jakarta: PT Raja Grafindo Persada.

Natsiopoulou et. al. (2010). An Innovative Preshool Health Education. Health Science Journal (4),110-117. [Online]. Available at: http://www.hsj.gr.

Puckett, M.B., dan Black, J.K. (2001). The Young Child. Development from Prebirth Through Age Eight. 3rd Edition. New Jersey: Merril Prentice Hall.

Putra, S. P. 2013. Obesitas Karena Kesalahan Pola Asuh, Mengganggu Perkembangan Psikologis Anak. https://mrcfkua.wordpress.com/2011 /12/13/gizi-berlebih-pada-anakpenyebab-dan-dampaknya/

Robertson, C. 2013. Safety, Nutrition, and Health in Early Education. 5th edition. United States: Wadsworth Cengange Learning.

Siswanto, H. 2010. Pendidikan Kesehatan Anak Usia Dini. Yogyakarta: Pustaka Rihama.

Shim, J.E., Juhee, K., Rose, A.M. 2011. Associations of Infant Feeding Practices and Picky Eating Behaviors of Preschool Children. Journal of the American Dietetic Association. 111, (9), 1363-1368.

Sugiyono. 2008. Metode Penelitian Pendidikan. Pendekatan Kuantitatif, Kualitatif dan R\&D. Bandung: Alfabeta.

Sullivan, H. (1981). Basic Nutrition in Health and Disease Including
Selection and Care of Food. London: W. B. Sounders Company. Ventura, A.K., Birch, L.L. 2008. Does Parenting Affect Children's Eating and Weight Status. International Journal of Behavioral Nutrition and Physical Activity 5:15,1479-5868. Online: http://www.ijbnpa.org/content/5/1/1 5

Wardle, J., etc. 2002. Parental Feeding Style and Inter-generational Transmission of Obesity Risk. Obes Res. $\quad 2002$ Jun;10(6):453-62. Pubmed.gov. Online: http://onlinelibrary.wiley.com/doi/10 .1038/oby.2002.63/full

www.health.detik.com. 